\title{
Providential dispensation of justice in Silas
}

\section{Marner}

\section{Dr. Vivek Chauhan}

Department of English, Sri Sathya Sai Institute, Bangalore, India

\begin{abstract}
This study is aimed at discovering the dispensation of justice to Silas, the character created by George Eliot. The study provides a look at the selective phases of the life of Silas to ultimately prove that providential dispensation of justice takes place towards the end when love and faith are restored to Silas Marner.

Keywords-Silas Marner; Eppie; William Dane; Church; Guineas; Dunstan; George Eliot; love, faith; Raveloe ; Lantern Yard; Weaver.
\end{abstract}

Silas Marner was published in the year 1861 and was considered by readers and critics alike as the masterpiece of George Eliot. The reason for the instant popularity of this novel was the fact that it had been modeled keeping in mind the development of a single and unique character Silas who is a common weaver of Raveloe. The simple story of rural England goes through the ups and downs of this simple, honest and religious minded weaver who has deep seated faith in God and hence his regular attendance at church. This regular humdrum of his mortal existence finds a nadir in the form of adverse circumstances that compel him to leave Lantern Yard and find refuge near a stone pit at the village of Raveloe. This great low in his life results in his loss of faith and deep withdrawal and introspection. As the story advances, things begin to clear up as decided by providence and Silas is cleared of all false charges levelled against him. Finally his faith returns when he finds life meaningful, offering his filial love to the orphaned child Eppie and getting her innocent love in return.

\section{George Eliot and her Works:}

Adam Bede published in 1859 was the first novel of George Eliot. This book is known for its masterly realism on account of the minute details of scenes that George Eliot has captured. Adam Bede won her universal acclaim since the book went through eight printings in a year. The Mill on the Floss was published in 1860 in which she returns to describing the scenes of her early life. Her great psychological subtlety that she evidently mastered in Silas
Marner is obviously observed even in this novel. Silas Marner, published in 1861, stands as her unique and masterly work. Its brevity and perfection make it her most popular work read by generation after generation of people ranging from children to elderly people. Middlemarch saw its complete publication in 1872 and came to be her masterpiece. It is through this novel that Eliot moved from an entertainer and a great psychologist to a great intellectual.

\section{The Germ of Silas Marner}

Silas Marner was inspired by an actual incident in life. Wilbur Lucius Cross (1903), in his introduction to Silas Marner observes the following about the origin of the inspiration to write Silas Marner: " It came to me," she says in a letter to her publisher, " first of all quite suddenly, as a sort of legendary tale, suggested by my recollection of having once, in early childhood, seen a linen weaver with a bag on his back."(Lucius, 1903, p.30)

\section{In Appreciation of the Work}

Silas Marner is a work of the mature and imaginative phase of the life of George Eliot. The work offers not just vivid descriptions of people and places; it has to its great credit wonderfully moulded characters of men who display the workings of their minds through their particular deeds; and the work of providence in rewarding or punishing individuals at the appropriate time and manner is also clearly pictured. This is what Edward.l.Gulick (1899) observes about the soundness of Silas Marner as a great work of art: 
Silas Marner is a story of one man and of his neighbors in so far as they are related to him; it has unity: Silas Marner is not confused by many details; it has simplicity: the theme of the story is not stated abstractly only, but it is expressed sensuously in the characters and action and dialogue, making an appeal to the imagination and all this is done with such skill and beauty as to charm the critic and the servant girl, the old and the young alike. It is, therefore, a work of art. (Gulick, 1899, p.xxi)

\section{Definition and Analysis of Key words as used in the title:}

The key words of this study have to be understood in the sense in which they are being used here for a better understanding and appreciation of the article. The first word that needs to be defined is Providential. This word is an adjective of the noun Providence which is defined as the care of God over created beings; Divine superintendence (Johnson, 1830, p.734) Providential therefore means everything that is provided by God when the time comes. Dispensation , according to Johnson's (1830)English Dictionary means distribution; dealing out anything; The dealing of God with His Creatures; distribution of good and evil.(Johnson,1830,p.299) It is with the last two connotations of the word that we are concerned in this study. Justice, according to Samuel Johnson is, the virtue by which we give to every man what is his due. (Johnson,1830,p.539)

\section{The Industrious Recluse}

Eliot opens the story describing the itinerant linen weavers of rural England as short individuals who carried a sack full of linen thrown back on their strong shoulder ; and who on account of the burden they carried were looked upon with suspicion by village folk and even the dogs barked when such small men were seen going across the village. Eliot immediately dives into the story describing Silas Marner as living a lonely existence in a sequestered hut near the stone pit of Raveloe village. The line that is used to show that Silas was leading a lonely life is so striking that we are tempted to associate the word 'deserted' as referring not just to the hut but also to Silas although Eliot may not have meant it as a transferred epithet.

This is how Eliot (1900) describes the protagonist of her book: In the early years of this century, such a linenweaver, named Silas Marner, worked at his vocation in a stone cottage that stood among the nutty hedgerows near the village of Raveloe, and not far from the edge of a deserted
stone-pit.(Eliot,1900,p.2) The very fact that the weaver lives at a stone cottage near a 'deserted stone-pit' is a cruel suggestion thrown out by the author to the readers of the stone hearts of our civilization.

\section{The desolation of Silas Explained}

Silas the linen weaver had now been living at the cottage for several years. He had come to Raveloe 15 years ago and had settled at the stone cottage for want of a better or cheaper shelter. This would enable him to weave linen and sell it to people in the village and also take fresh orders from folk who wanted fresh linen. However it may be, his nature of total withdrawal from society caused multiple conjectures from various quarters regarding his individuality. The effective natural cures that he offered for many ailments made him an object of awe and fear rather than confidence among the village folk. He hardly interacted with anybody in Raveloe except on occasions when he would buy necessities or sell linen in the village. The belief in demon-worship was among those rural folk so prevalent that people could hardly "associate the ideas of power and benignity" (Eliot, 1900, p.3)

Their fears that the weaver might be the agent of the devil made them keep away from the weaver and avoid interacting with him as far as possible. The desolation of Silas was thus complete; first on the account of his own introspective nature and secondly because of the superstitious fears that the village folk entertained about him that he might cause them harm if hurt psychologically.

\section{The Victim of Superstition}

Before settling in Raveloe, Silas had been an inhabitant of a little town called Lantern Yard. Full fifteen years had elapsed since he came to Raveloe and these fifteen years had wrought a sea change in the young weaver. His entire cheerful disposition had abandoned him and he came to be the isolated individual whom we observe working in silence at his stone cottage; and only his loom creating the regular sounds of weaving.

His singular attitude and his isolated weaving at his loom has a strange fascination for the Raveloe boys. While they would try to peep in at his work and disturb him; he hardly liked their intrusion and would sometimes descend from his loom and going close to them would throw such a terrifying look to them with his large rounded eyes that they would immediately take to their heels. This stare of Silas was so well known in Raveloe in the course of 15 years that it carried a great superstition with it. This is what George Eliot 
proclaims: "For how was it possible to believe that those large brown protuberant eyes in Silas Marner's pale face really saw nothing very distinctly that was not very close to them, and not rather that their dreadful stare could dart cramps, or rickets,or a wry mouth at any boy who happened to be in the rear?"

(Eliot, 1900, pp.2-3)

\section{Loss of Faith}

When Silas was in Lantern Yard, an enthusiastic young man, his piety ever ready to serve the church; he was unjustly blamed for the loss of the church money that had actually been stolen by William Dane who had pretended to be the friend of Silas. This William Dane could not bear the growing popularity of Silas among the Lantern Yard people and therefore in order to break the engagement between Silas and Sarah, he wove an evil plot. When Silas had been attending to the bedridden deacon at church, William stole the church money and placed the bag in Silas's stone cottage. When the church money was discovered at the stone cottage Silas was tried at the church; and subsequently when Silas could not defend himself and prove his innocence, he was asked to accept his guilt and leave Lantern Yard at once. All the pleas of Silas were of no avail and he was thus banished from Lantern Yard, a psychologically broken man who lost faith in friendship and in God. Soon Sarah broke the engagement and married William Dane. Silas left Lantern Yard forever and settled at Raveloe.

\section{Loss of the Hard Earned Guineas}

Silas Marner was an industrious man by all measures and his hard work lay in not only weaving the linen but also going out for the raw material and taking orders for the linen. Marner had minimum bodily wants and therefore he used to save up his guineas in the ground of the cottage, removing a few bricks and stowing away the leather pouch filled with guineas into the hole. Subsequently he would put back the bricks and cover up the hole and sprinkle sand upon it to remove traces of his treasure trove.

In the evenings he would warm himself at his candle and sit down to enjoy the company of the gold coins before his supper. One such evening when he was to sit down to supper, he wished to have a view of his guineas. As soon as he removed the bricks he was in for a shock. This is how Eliot describes the shocking experience of Silas:

For joy is the best of wine, and Silas's guineas were golden wines of that sort. He rose and placed his candle unsuspectingly on the floor near his loom, swept away the sand without noticing any change, and removed the bricks. The sight of the empty hole made his heart leap violently, but the belief that his gold was gone could not come at once - only terror, and the eager effort to put an end to the terror. (Eliot, 1900, pp.36)

\section{Providential Assistance: Eppie and the return of Faith and gold}

The sad life of Silas who sat moaning for several days for the loss of his hard earned gold gradually found solace in the form of the new found treasure - Eppie, the gold haired girl child whom Silas had adapted when the infant had come crawling to his stone hut and the child's mother had been found dead in the snow.

Silas brought her up and her innocent love gave new meaning to his life and the lost purpose of existence had returned to him; and with that his faith in God began to be restored.

The bad had been punished and the good rewarded. Dunstan, who had robbed Silas of his hard earned money; and who had been missing for 16 years was found dead in the stone pit - his skeleton holding the leather bag containing the gold belonging to Silas. The gold was finally restored to Silas with which he married Eppie to her lover Aaron and made her happy in life.

The providential punishment has been very artistically depicted by George Eliot (1900):

Oh, Godfrey! "She said, with compassion in her tone, for she had immediately reflected that the dishonor must be felt still more keenly by her husband." There was the money in the pit," he continued - "all the weaver's money. Everything's been gathered up, and they're taking the skeleton to the Rainbow. But I came back to tell you: there was no hindering it ; you must know. (Eliot, 1900, pp.144)

\section{CONCLUSION}

Justice is done when Silas Marner finds the purpose of life finds the love of God in the form of Eppie and finds justice when his hard earned money is restored to him providentially. Silas Marner, an old man now, is happy with the faith in God returning to him and hence his faith in man is consequently restored. This is what Barbara Goodman observes: Such is the process that redeems Silas from a 
International Journal of English Literature and Social Sciences, 5(4)

Jul-Aug 2020 /Available online: https://ijels.com/

meaningless existence. Its issue, as we have seen, is a restoration of love and faith.(Goodman,2000,p.160)

\section{REFERENCES}

[1] Eliot, George. Silas Marner, Essays. New York: The Kelmscott Society Publishers, 1900

[2] Goodman, Barbara. A. Readings on Silas Marner. San Diego: Greenhaven Press,2000,p.160

[3] Gulick, Edward Leeds. Silas Marner by George Eliot. New York: The Macmillan Company, 1899, p.xxi

[4] Johnson, Samuel. Johnson's English Dictionary. Boston: Perkins and Marvin, 1830, pp.734,299,539

[5] Lucius Cross, Wilbur. Silas Marner by George Eliot. New York: American Book Company, 1903,p.30 